\title{
The Wave Climate of the Sea of Azov
}

\author{
Natalia Yaitskaya 1,2 (D)
}

Citation: Yaitskaya, N. The Wave Climate of the Sea of Azov. Water 2022, 14, 555. https://doi.org/ 10.3390/w14040555

Academic Editor: Chih-Chieh Young

Received: 11 January 2022

Accepted: 9 February 2022

Published: 12 February 2022

Publisher's Note: MDPI stays neutral with regard to jurisdictional claims in published maps and institutional affiliations.

Copyright: (C) 2022 by the author. Licensee MDPI, Basel, Switzerland. This article is an open access article distributed under the terms and conditions of the Creative Commons Attribution (CC BY) license (https:/ / creativecommons.org/licenses/by/ $4.0 /)$.
1 Federal Research Center the Subtropical Scientific Center of the Russian Academy of Sciences, 354002 Sochi, Russia; yaitskayan@gmail.com

2 Federal Research Center the Southern Scientific Center of the Russian Academy of Sciences, 344006 Rostov-on-Don, Russia

\begin{abstract}
This article describes the results of the retrospective numerical simulation of wind waves in the Sea of Azov using the SWAN spectral wave model and the ERA-Interim global reanalysis for 1979-2019. A digital model of the sea-floor relief of the Sea of Azov was used for the calculations. This model was built using a bathymetric map of the Sea of Azov, as well as nautical charts and remote sensing data. Verification of the model for the conditions that characterize the Sea of Azov was conducted using data from ship observations of wind waves. The features of the mean longterm wind wave patterns, as well as the seasonal, interannual, and interdecadal dynamics were presented. The main focus was on the following parameters: significant wave height, wave period, and wave direction. A description of storm conditions and a comparison with surge phenomena and ice conditions was also completed. The results indicated that, in contrast to Taganrog Bay, the wave patterns were heavily influenced according to the time of year (i.e., the seasons). The maximum wave heights were typical for the cold season of the year but not for the ice-free period. The interannual dynamics of wind waves were characterized by the alternation of three five-year periods of strengthening and weakening of wind waves. After 2002, the wave height increased in the summer and autumn seasons and slightly decreased in winter and spring. A shift of the storm season to a warmer period was also detected.
\end{abstract}

Keywords: the Sea of Azov; wave climate; storm; surges; retrospective analysis; mathematical modeling

\section{Introduction}

Climatic conditions determine the vital activity and development in different regions of the planet. As a result of their influence, regions and countries have developed specific economic and social policies, and appropriate infrastructure has been built for sensitive industries, such as farming and shipping. For centuries, we have been trying to establish a harmonious relationship with the natural world, whether that involves embracing the benefits of a favorable climate or learning to adapt to a harsher one. However, despite some successes in striking that balance, dangerous natural phenomena still occur, both exogenous and endogenous. Climatic and natural conditions make some regions of the planet more likely locations for dangerous phenomena. Despite technological advancements, we remain unable to control the weather patterns. With the assistance of accurate forecasting methods, which have developed and improved significantly in the 21st century, we are able to take preventative measures and avoid catastrophes, but only under certain conditions and circumstances. Under others, we are powerless.

In addition to the economic and physical damages caused by natural hazards, as described in reports, reference books, and mass media, the degree of interdependence and mutual conditionality of natural and social processes as feedback in the nature-man relationship has not yet been determined. Natural disasters have been the foundation for social and political upheavals at various times [1]. In addition, these events have also had positive impacts, such as revealing the inefficiency of regional and departmental 
administrations, as well as the errors and the miscalculations of environmental monitoring and social forecasting, resulting in delays in detrimental actions.

Within the Russian Federation, the southern macroregion has been of particular interest as it has access to three seas, the Sea of Azov, the Black Sea, and the Caspian Sea. This access has had great economic importance by supporting traditional trade routes and the formation of cultural ties between western and eastern states, as well as having encouraged significant ethno-cultural, religious, and national diversity that often accompany large tourist and recreational destinations and developed coastal infrastructure [2]. Due to the geographical location, orography, and hydrometeorological features, the region is characterized by periodic events of dangerous hydrometeorological phenomena, including storms as well as up and down surges; rainfall and water floods; abnormally hot weather; and early ice formation along with severe winters and their various combinations [3]. These events are often difficult to predict, as they rely not only on global climatic patterns but can also be heavily influenced by climate changes, especially the anthropogenic effects on the environment. Moreover, the phenomena themselves affect the social and political stability of the macroregion directly and indirectly.

Comprehensive research and reliable scientific conclusions have assisted in improving accurate predictions of major weather events, but observations at coastal hydrometeorological stations and at sea have not always been conducted for long periods of time and at consistent geographical locations. Therefore, mathematical models verified by field observations have become important research tools.

Currently, a number of models are used for retrospective analyses of wave climates for water bodies of various scales. For shallow waters, the Simulating Waves Nearshore (SWAN) model has been developed. It has been effectively used by a number of research teams for the long-term development of research and modeling concerning wind waves. In [4], the present situation in wave modeling science was demonstrated, particularly in regard to the inner and coastal seas.

Another study developed and validated a flexible wave-prediction system to provide information about the wave conditions at the entrance of Portuguese ports [5]. A multilevel system for modeling the wave transformations, based on SWAN, was successfully implemented across the entire west Iberian nearshore and validated using buoy data. The hindcast, nowcast, and forecast schemes were evaluated and discussed. An analysis of coastal processes, such as diffraction and triad wave-wave interactions was also conducted.

In addition, significant results were published on the calculation of the spectral characteristics of waves using the SWAN model [6]. Another study reported that structured-grid models had the ability to capture the wave dynamics of large-scale offshore domains, and the unstructured meshes provided an opportunity to better simulate shallow water waves by resolving the complex geometry along islands and coastlines [7]. In their study, wind waves in Lake Michigan were simulated using the unstructured-grid version of the SWAN model with various types of wind forces, and the model was calibrated using in situ wave observations.

Recently, the calculations of wind waves in the Baltic Sea were successfully performed using a third-generation SWAN spectral wave model [8]. This approach identified 2943 storm events, including approximately 50 storms per year during 1948-2010. The authors identified conditions as "stormy" if the significant wave height reached $2 \mathrm{~m}$. According to their results, a unidirectional linear trend of increasing storm activity in the Baltic Sea was clearly distinguished. Similar studies were conducted for the Barents Sea [9]. Based on the simulation results, a calendar of storms (wave height $\mathrm{h}>=4 \mathrm{~m}$ ) in the Baltic, Black, and Caspian Seas was compiled for 1948-2010 [10], which was then used by the authors for the climatic forecast of extreme hydrometeorological phenomena. The authors also proposed a method for climate prediction that identified the causes that could be related to dangerous hydrometeorological phenomena including, in particular, a storm phenomenon [10]. In addition, the Caspian Sea wave climate was reconstructed on the 
basis of the SWAN and National Centers for Environmental Prediction and the National Center for Atmospheric Research (NCEP/NCAR) Reanalysis Project during 1949-2016 [11].

Previous studies have also conducted the mathematical modeling of wind waves in the Black Sea [12-15]. Using the SWAN model and modern analysis, the wave climate of the Black Sea has been calculated, the spatiotemporal features of the waves have been revealed, and the calculation results were validated using the observational data from buoys. Furthermore, various calculation schemes with variations in physical parameters were analyzed.

Recently, prediction blocks for storm wave were developed for the Sea of Azov using the EX-MARE forecasting system [16]. This has enabled the development of a hindcast system.

This paper describes the results of retrospective, numerical simulation of the wind waves in the Sea of Azov during 1979-2019. Using mathematical modeling and global reanalysis based on high-precision bathymetric data, we compared storm surges and ice patterns. The results may improve our understanding of the climate impact on the region and the variable parameters of wind waves during ice-free periods.

\section{Materials and Methods}

\subsection{Description of the Model}

For a retrospective analysis of wind waves in the Sea of Azov, the Simulating Waves Nearshore (SWAN) mathematical model, version 41.31, was used to obtain realistic parameters for a given wind, bathymetry, and current conditions in shallow waters, such as those found in coastal regions, lakes, and estuaries. The model was developed at the Faculty of Civil Engineering and Earth Sciences of Delft Technical University, Netherlands. The model has been described in [17-20]. As mentioned above, this model has been used to calculate waves occurring among the inland seas of Russia, and it has been widely used with reliable results for both deep-water and shallow, closed-water areas. Moreover, at the time of publication, the model was actively supported by the developers, who released regular updates and new versions accompanied by clarifications of physical parameters and additions.

\subsection{Study Area and Initial Data}

The Sea of Azov is located in east Europe along the coasts of Ukraine and Russia. It is also the shallowest sea in the world: The depth does not exceed $13.5 \mathrm{~m}$ at any point, and the average depth is about $7.4 \mathrm{~m}$. The area of greatest depth is located at the center of the sea. The isobaths are almost symmetrical. The sea length, at its longest point, is $380 \mathrm{~km}$ while its width, as the widest point, is $200 \mathrm{~km}$. In winter, partial or complete freezing is possible while its ice is carried into the Black Sea via the Kerch Strait, and ice formation is typical between January and February. The largest connected rivers are Don and Kuban. Northeast of the Sea of Azov lies Taganrog Bay, and the Kerch Strait lies in the south, which connects it to the Black Sea.

For calculations in the SWAN model, a digital elevation model (DEM) of the bottom of the Sea of Azov was used. It was built according to a bathymetric map of the Sea of Azov [21,22], 1:500,000- and 1:25,000-scale nautical navigation maps, and remote sensing data captured by the Landsat 8 satellite [23]. Based on this DEM, a computational grid with a spatial resolution of $0.01 \times 0.01$ was developed [24]. Calculations were performed for each mesh at each time step. Additionally, calculations were made at five points, characterizing certain areas of the sea (Figure 1) in accordance with the zoning of the Azov Research Institute of Fisheries [25] and oceanographic measurement station grid. Point 06, the eastern part of Taganrog Bay, corresponded to the position of the stationary hydrometeorological post of the Southern Scientific Center of the Russian Academy of Sciences in the Don Delta, where observations have been regularly recorded since 1997. Point X4, the central part of the Sea of Azov, is located in the deepest part of the sea. Points 05,03 , and 04 were located on the fairway of the Kerch Strait and corresponded to 
the northern, central, and southern parts of the Strait, respectively, and characterize the transformation of wind waves when moving along a narrow strait from the deep-water Black Sea to the shallow water Sea of Azov. All the selected points were located on the route of the Taganrog-Kerch navigation channel.

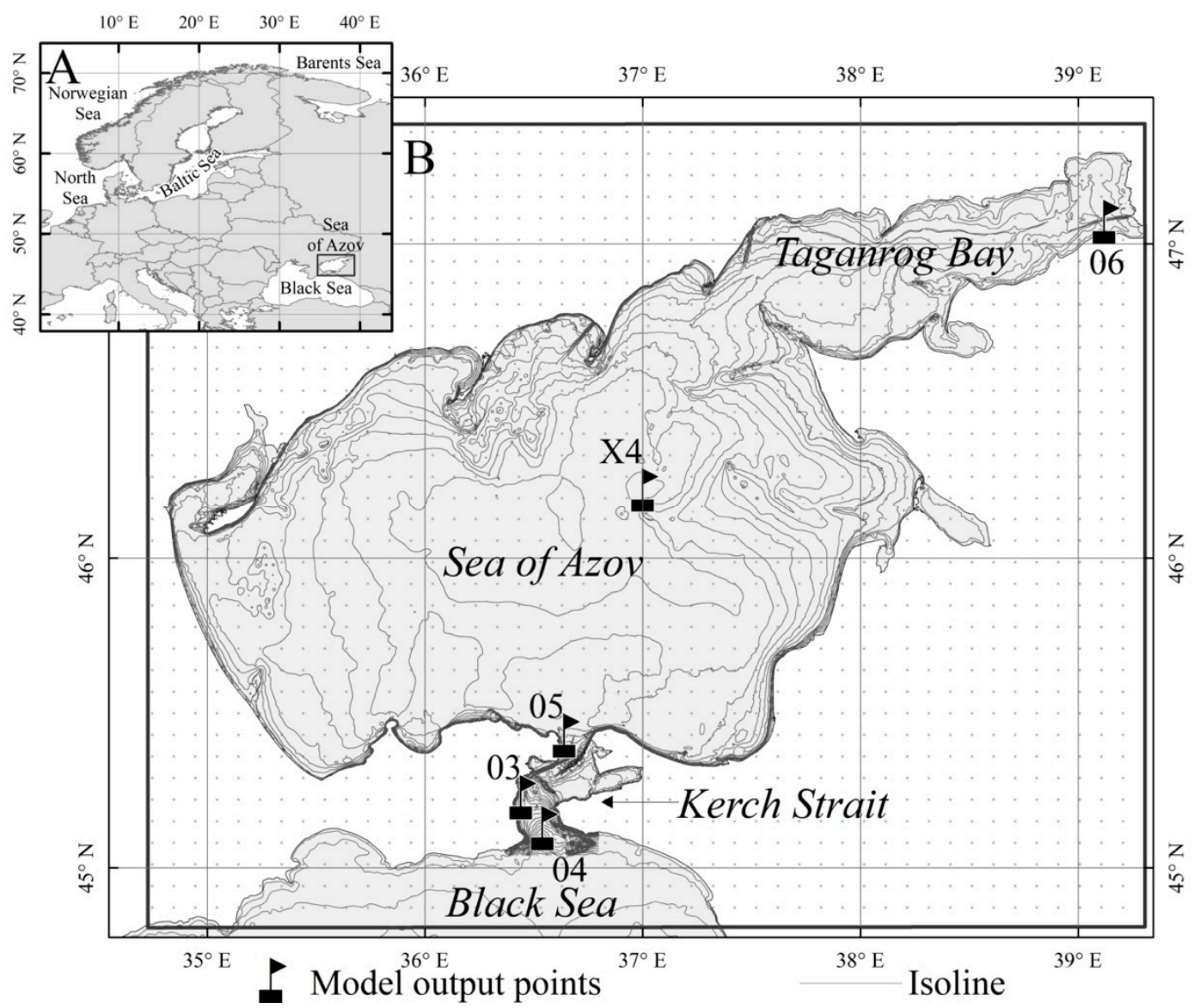

Figure 1. The study area. (A) - geographical location of the analyzed area on the Europe map. (B) - the boundaries of the computational grid for the SWAN model.

The global atmospheric reanalysis of the European Centre for Medium-Range Weather Forecasts European Reanalysis ERA-Interim [26] was used for wind forces using sets of zonal and meridional components at an altitude of $10 \mathrm{~m}$ above sea level, available from 1 January 1979 to 31 August 2019. The discrete time was $1 \mathrm{~h}$. The spatial resolution of the reanalysis grid was approximately $80 \mathrm{~km}$. Interpolation of the nodes of the calculated grids was not performed in order to avoid the accumulation of errors during recalculations. Due to the wind fields over the Sea of Azov not demonstrating significant variability over time, there was no requirement increase the wind-grid calculations or conduct a reanalysis with a large number of nodes.

The final datasets, in the form of text files, were used as input information for the SWAN model.

\subsection{Verification and Parameterization of the Model}

Verification of the SWAN model for the conditions of the Sea of Azov was performed for "storm" and "normal" conditions, and described in the other studies [24,27]. Test calculations were conducted using the default parameters for the time intervals with average and storm wind waves (regardless of the season), as controls; each physical process preset in the model was sequentially checked, and the necessary coefficients were selected. Information concerning individual storms was sourced from the archives and 
other academic sources. In situ passing measurements of wave-height and direction were completed using, in part, the observation data of waves from the Unified State System of Information on the World Ocean (ESIMO) [28] digital archive. All data were used to verify the results while validating and calibrating the model. Information quality control had already been performed for all observational data prior to the start of the study, including peak values and the compliance of measurements with time zones.

Basic processes and coefficients were included in the final calculations including wind input; linear wave growth in accordance with the approach outlined in [29]; dissipation by bottom friction; bottom friction parameterized by the JONSWAP spectrum constant [30]; white-capping; nonlinear wave-wave interactions (quadruplets and triads); and waveinduced setup.

The time steps of calculations were in 15 min intervals since 1 January 1979. The analysis of the results included only the winter months when the sea-ice concentration reached $20 \%$ or less. These values were determined on the basis of our own data archives on the ice patterns of the Sea of Azov [31]. At each time step, the values of the desired parameters were calculated for each mesh and recorded in output files. The values of external factors (e.g., wind speed and direction) changed every hour. The SWAN model calculated the values of wind wave characteristics including significant wave height; average (zero and minus the first moments of the spectrum) period; wave direction and length; and swell parameters.

According to Matishov et al. [32], the currents in the Sea of Azov are drifting, depending on the wind direction due to depth and size limitations. Which does not allow the formation of constant cyclonic currents and make a significant contribution to surge phenomena and wind waves.

During the wind wave calculation, the following parameters were prioritized: significant wave height $(\mathrm{m})$ and wave period (sec), as well as direction (deg.). The seasons were defined as: winter-December, January, February; spring-March, April, May; summerJune, July, August; and autumn-September, October, November.

\section{Results}

\subsection{Average Long-Term Wind-Wave Pattern in the Sea of Azov}

A clearly pronounced seasonality was identified as a main characteristics of wind waves (Figure 2). Due to the shallow water, small size, and almost complete isolation, the wave direction and intensity in the Sea of Azov corresponded to the direction of prevailing winds and were correlated with speed. Maximum wave heights of up to $3 \mathrm{~m}$ (with an average of up to $0.8 \mathrm{~m}$ ) were typical for the annual cold seasons. From October to April, the winds of the northern and north-eastern components prevailed in the Sea of Azov, which was also under the influence of the Siberian anticyclone spur. At this time of year, the wavelength in the central part of the sea has reached $14 \mathrm{~m}$ or more. A limiting factor, while simultaneously being a protective element for the abrasive seacoast during an active storm surge, the presence of a strong ice cover has been observed annually from December to March. Due to storm activity, ice piles have often been observed on the coast of the Sea of Azov in late winter and spring.

In the warm parts of the year, during the activation of the Azores anticyclone, the prevailing wind direction changed to south-west and west. Along with the wind, the direction also changed the wind waves. The wave height decreased to $0.2 \mathrm{~m}$, and calm was often observed. At this time, the maximum wave height in the deepest central part of the sea could reach $2-2.5 \mathrm{~m}$. Only once within the last 40 years, a destructive storm with a wave height pf up to $3.5 \mathrm{~m}$ was recorded in September 2014.

In the Kerch Strait, the direction of wind waves differed due to the narrowness, as well as the presence of braids and extensive shoals. The north and south directions were predominant. The average and maximum wave heights in the Strait reached $0.6 \mathrm{~m}$ and $2.5 \mathrm{~m}$, respectively. 
The highest values of wave heights were reached in the central part of the sea, and the lowest were found north of Taganrog Bay and in the central part of the Kerch Strait. The areas with the lowest values of wave height were characterized by the least storm activity as well. There were almost no seasonal dynamics in Taganrog Bay (Figure 3).
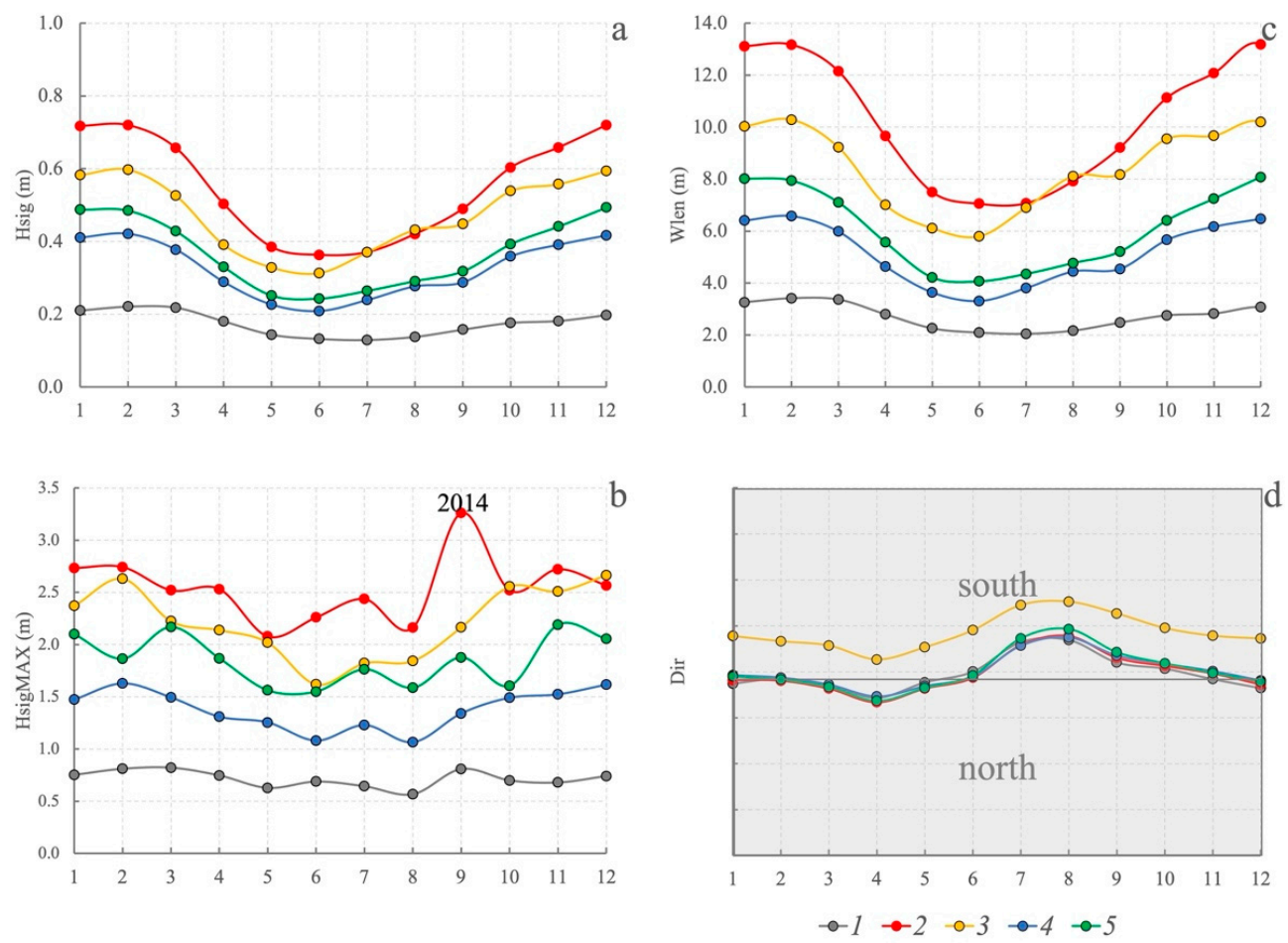

Figure 2. The average long-term seasonal dynamics of the main parameters of wind waves by months. (a) The average height of significant waves. (b) The maximum height of significant waves. (c) The average wavelength. (d) The average direction of wind waves. Where 1 is Taganrog Bay; 2 is the center of the Sea of Azov; 3, 4, 5 are the north, center, and south of the Kerch Strait, respectively.

Statistical properties for the results of the calculated wave parameters are summarized in Table 1. Where Hsig-significant wave height $(\mathrm{m})$, Wlen—average wavelength $(\mathrm{m})$, Tm—wave period (sec.), Swell—swell wave height (m).

Table 1. Statistical properties of calculated wave parameters: significant wave height (Hsig, $\mathrm{m}$ ), average wavelength (Wlen, m), wave period (Tm, s.), swell wave height (Swell, m).

\begin{tabular}{cccccc}
\hline & Average & Maximum & $\begin{array}{c}\text { Standard } \\
\text { Deviation }\end{array}$ & Dispersion & Location \\
\hline Hsig (m) & 0.55 & 3.26 & 0.43 & 0.18 & \\
Wlen (m) & 10.25 & 48.49 & 7.16 & 51.29 & Sea of Azov \\
Tm (s.) & 2.89 & 6.78 & 0.95 & 0.91 & \\
Swell (m) & 0.00 & 0.48 & 0.00 & 0.00 & \\
\hline Hsig (m) & 0.17 & 0.82 & 0.12 & 0.01 & \\
Wlen (m) & 2.71 & 10.97 & 1.84 & 3.40 & Taganrog Bay \\
Tm (s.) & 1.56 & 3.22 & 0.44 & 0.20 & \\
Swell (m) & 0.00 & 0.02 & 0.00 & 0.00 & \\
\hline Hsig (m) & 0.37 & 2.19 & 0.28 & 0.08 & \\
Wlen (m) & 6.07 & 31.98 & 4.46 & 19.94 & Kerch Strait \\
Tm (s.) & 2.23 & 5.40 & 0.78 & 0.61 & (north) \\
Swell (m) & 0.00 & 0.09 & 0.00 & 0.00 & \\
\hline
\end{tabular}


Table 1. Cont.

\begin{tabular}{cccccc}
\hline & Average & Maximum & $\begin{array}{c}\text { Standard } \\
\text { Deviation }\end{array}$ & Dispersion & Location \\
\hline Hsig (m) & 0.32 & 1.63 & 0.25 & 0.06 & \\
Wlen (m) & 5.13 & 23.27 & 3.76 & 14.12 & Kerch Strait \\
Tm (s.) & 2.05 & 4.73 & 0.70 & 0.49 & (center) \\
Swell (m) & 0.00 & 0.06 & 0.00 & 0.00 & \\
\hline Hsig (m) & 0.47 & 2.67 & 0.36 & 0.13 & \\
Wlen (m) & 8.41 & 39.57 & 6.04 & 36.53 & Kerch Strait \\
Tm (s.) & 2.73 & 6.41 & 0.92 & 0.84 & (south) \\
Swell (m) & 0.00 & 0.26 & 0.01 & 0.00 & \\
\hline
\end{tabular}
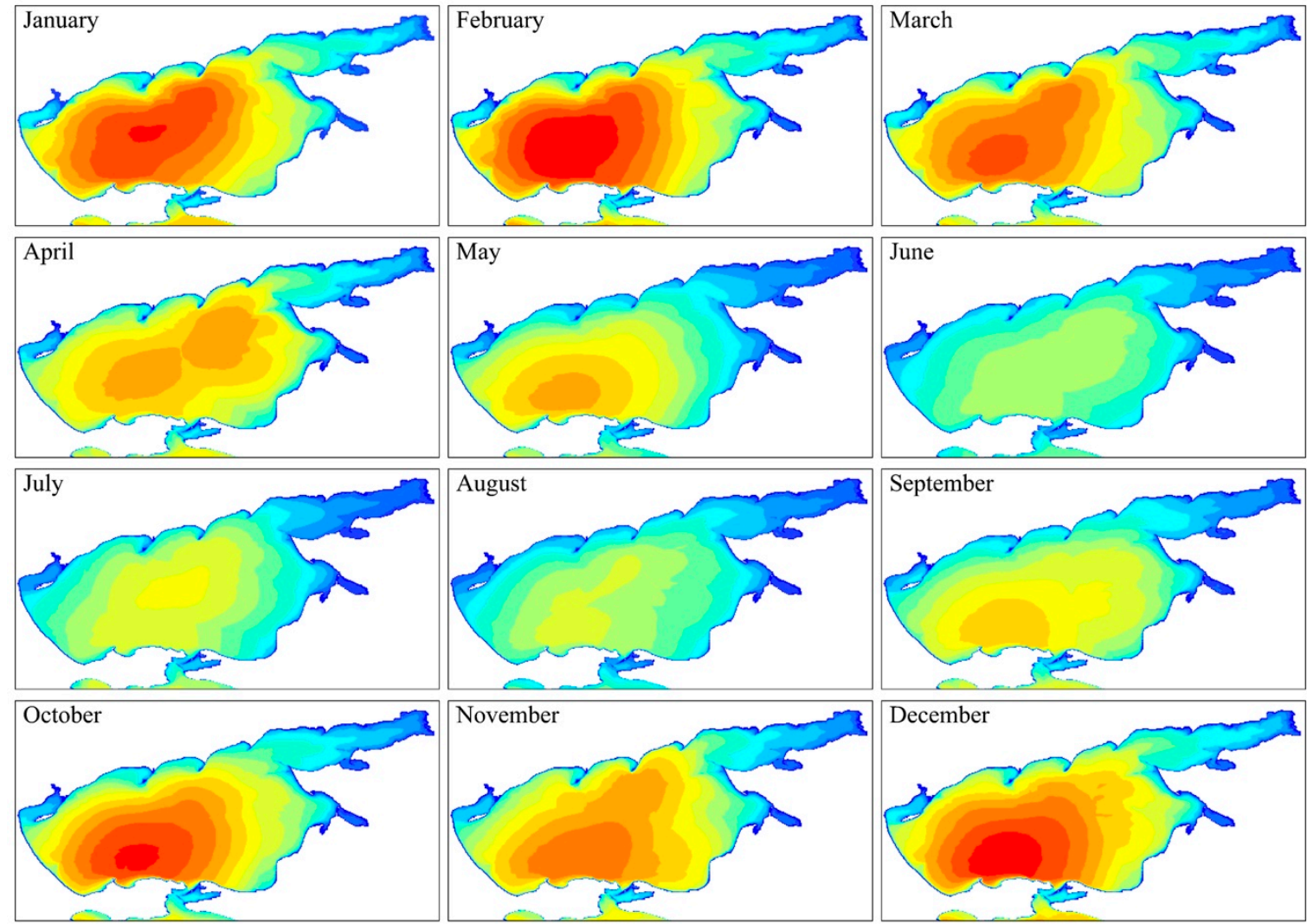

\section{Hsig (m)}

$0.0-0.2 \square 0.5-0.6 \square 0.9-1.0 \square 1.3-1.4 \square 1.7-1.8 \square 2.1-2.2 \square 2.5-2.6 \square 2.9-3.0$

$0.3-0.4 \square 0.7-0.8 \square 1.1-1.2 \square 1.5-1.6 \square 1.9-2.0 \square 2.3-2.4 \square 2.7-2.8 \square 3.1-4.0$

Figure 3. Long-term maximum wave height (m) in the Sea of Azov according to calculations.

\subsection{Interannual Dynamics of Wind Waves}

To analyze the interannual variability of wind waves, we considered the anomalies of long-term averages, using the variabilities identified during ten-year periods (Table 2). Color gradient - the dynamics of each parameter relative to each other over decades from the largest (dark blue) to the smallest (white) values. 
Table 2. Average parameters of wind waves across decades for seasons: significant wave height (Hsig, $\mathrm{m})$, average wavelength (Wlen, $\mathrm{m})$, wave period $(\mathrm{Tm}, \mathrm{s})$.

\begin{tabular}{|c|c|c|c|c|c|c|c|c|c|c|c|c|c|}
\hline & $\begin{array}{c}\text { Hsig } \\
(\mathrm{m})\end{array}$ & $\begin{array}{l}\text { Winter } \\
\text { Wlen } \\
\text { (m) }\end{array}$ & $\operatorname{Tm}(\mathrm{s})$ & $\begin{array}{c}\text { Hsig } \\
(\mathrm{m})\end{array}$ & $\begin{array}{c}\text { Spring } \\
\text { Wlen } \\
\text { (m) }\end{array}$ & $\operatorname{Tm}(\mathrm{s})$ & $\begin{array}{c}\text { Hsig } \\
(\mathrm{m})\end{array}$ & $\begin{array}{l}\text { Summe } \\
\text { Wlen } \\
\text { (m) }\end{array}$ & $\operatorname{Tm}(\mathrm{s})$ & $\begin{array}{c}\text { Hsig } \\
(\mathrm{m})\end{array}$ & $\begin{array}{c}\text { Autum } \\
\text { Wlen } \\
\text { (m) }\end{array}$ & $\operatorname{Tm}(\mathrm{s})$ & \\
\hline 1980-1989 & 0.22 & 3.33 & 1.70 & 0.18 & 2.81 & 1.58 & 0.12 & 1.87 & 1.37 & 0.18 & 2.80 & 1.58 & \multirow{4}{*}{ Taganrog Bay } \\
\hline 1990-1999 & 0.22 & 3.34 & 1.71 & 0.19 & 2.95 & 1.62 & 0.14 & 2.15 & 1.43 & 0.17 & 2.67 & 1.56 & \\
\hline 2000-2009 & 0.20 & 3.06 & 1.65 & 0.17 & 2.71 & 1.57 & 0.14 & 2.20 & 1.44 & 0.17 & 2.60 & 1.53 & \\
\hline 2010-2019 & 0.21 & 3.21 & 1.68 & 0.18 & 2.76 & 1.58 & 0.14 & 2.19 & 1.44 & 0.18 & 2.74 & 1.57 & \\
\hline $1980-1989$ & 0.76 & 13.80 & 3.35 & 0.53 & 9.97 & 2.84 & 0.34 & 6.49 & 2.36 & 0.61 & 11.22 & 3.02 & \multirow{4}{*}{$\begin{array}{l}\text { The Sea of } \\
\text { Azov }\end{array}$} \\
\hline 1990-1999 & 0.74 & 13.51 & 3.32 & 0.54 & 10.30 & 2.92 & 0.39 & 7.50 & 2.51 & 0.57 & 10.63 & 2.94 & \\
\hline 2000-2009 & 0.67 & 12.38 & 3.19 & 0.49 & 9.44 & 2.80 & 0.41 & 7.74 & 2.56 & 0.57 & 10.55 & 2.94 & \\
\hline 2010-2019 & 0.67 & 12.42 & 3.18 & 0.49 & 9.38 & 2.78 & 0.40 & 7.63 & 2.53 & 0.60 & 10.96 & 2.97 & \\
\hline 1980-1989 & 0.60 & 10.34 & 3.03 & 0.43 & 7.72 & 2.60 & 0.32 & 5.92 & 2.33 & 0.52 & 9.24 & 2.88 & \multirow{4}{*}{$\begin{array}{l}\text { Kerch Strait } \\
\text { (north) }\end{array}$} \\
\hline 1990-1999 & 0.61 & 10.44 & 3.04 & 0.42 & 7.56 & 2.60 & 0.37 & 6.98 & 2.51 & 0.50 & 8.79 & 2.78 & \\
\hline 2000-2009 & 0.57 & 9.85 & 2.94 & 0.41 & 7.41 & 2.57 & 0.39 & 7.36 & 2.58 & 0.51 & 9.02 & 2.83 & \\
\hline 2010-2019 & 0.57 & 9.77 & 2.93 & 0.40 & 7.15 & 2.52 & 0.40 & 7.52 & 2.59 & 0.55 & 9.64 & 2.91 & \\
\hline 1980-1989 & 0.42 & 6.54 & 2.32 & 0.30 & 4.87 & 2.00 & 0.22 & 3.45 & 1.72 & 0.34 & 5.43 & 2.10 & \multirow{4}{*}{$\begin{array}{l}\text { Kerch Strait } \\
\text { (central part) }\end{array}$} \\
\hline 1990-1999 & 0.42 & 6.49 & 2.31 & 0.30 & 4.84 & 2.01 & 0.24 & 3.87 & 1.80 & 0.33 & 5.25 & 2.06 & \\
\hline 2000-2009 & 0.41 & 6.43 & 2.30 & 0.30 & 4.75 & 1.99 & 0.25 & 3.98 & 1.83 & 0.35 & 5.50 & 2.12 & \\
\hline 2010-2019 & 0.41 & 6.33 & 2.28 & 0.29 & 4.62 & 1.95 & 0.26 & 4.14 & 1.85 & 0.37 & 5.77 & 2.15 & \\
\hline 1980-1989 & 0.49 & 8.03 & 2.58 & 0.33 & 5.52 & 2.14 & 0.25 & 4.09 & 1.88 & 0.38 & 6.28 & 2.28 & \multirow{4}{*}{$\begin{array}{l}\text { Kerch Strait } \\
\text { (south) }\end{array}$} \\
\hline 1990-1999 & 0.49 & 8.06 & 2.58 & 0.34 & 5.73 & 2.19 & 0.27 & 4.40 & 1.93 & 0.37 & 6.12 & 2.24 & \\
\hline 2000-2009 & 0.49 & 7.99 & 2.57 & 0.34 & 5.74 & 2.17 & 0.28 & 4.57 & 1.97 & 0.39 & 6.34 & 2.29 & \\
\hline 2010-2019 & 0.47 & 7.79 & 2.54 & 0.34 & 5.68 & 2.15 & 0.28 & 4.56 & 1.97 & 0.40 & 6.54 & 2.32 & \\
\hline
\end{tabular}

Deviations of up to $0.13 \mathrm{~m}$ for the central part of the Sea of Azov were detected. The longest period, when the wave heights were below the average annual values, was 2002-2013, with only a few exceptions. However, the deviation values were not significant (within 0.05 ), which could be contributed to calculation error.

The years with the greatest increase in average heights did not typically coincide with the years that had the greatest increase in maximum wave heights. Moreover, since 2008, after a short decrease in maximum wave heights, a gradual increase in such values has been recorded.

In general, the wind wave dynamics for all areas of the sea were synchronous, with the exception of Taganrog Bay. After 2000, the values of the maximum wave heights stabilized or even decreased in the Bay.

In addition, the interannual variability of the direction of the wind waves reached 100 degrees or more.

\subsection{Storm and Its Combination with Surge and Dangerous Ice Phenomena}

According to the instructions for the preparation and transmission of storm messages by the observation units of Guidance Document 52.04.563-2013 and the list and criteria of dangerous natural hydrometeorological phenomena approved by the Order of the Federal State Budgetary Institution "North Caucasian Administration for Hydrometeorological and Environmental Monitoring" dated 26 February 2016, number 22, with amendments approved by the orders of the Federal State Budgetary Institution "North Caucasian Administration for Hydrometeorological and Environmental Monitoring" dated 17 May 2016, number 69; dated 22 June 2016, number 81; and dated 30 May 2017, number 65, strong waves in the Sea of Azov were defined as waves with a wave height of $3.0 \mathrm{~m}$ or greater, and a dangerous surge in Taganrog Bay was defined as a level of $700 \mathrm{~cm}$ or greater.

Depending on the prevailing wind direction, the region of maximum waves shifted from the center of the sea, with the greatest depths, to the southwest or northeast. The maximum wave heights, according to the calculation results, were observed in 1979, 1988, 1989, 1997, 2012, and 2014 (Figure 4). 


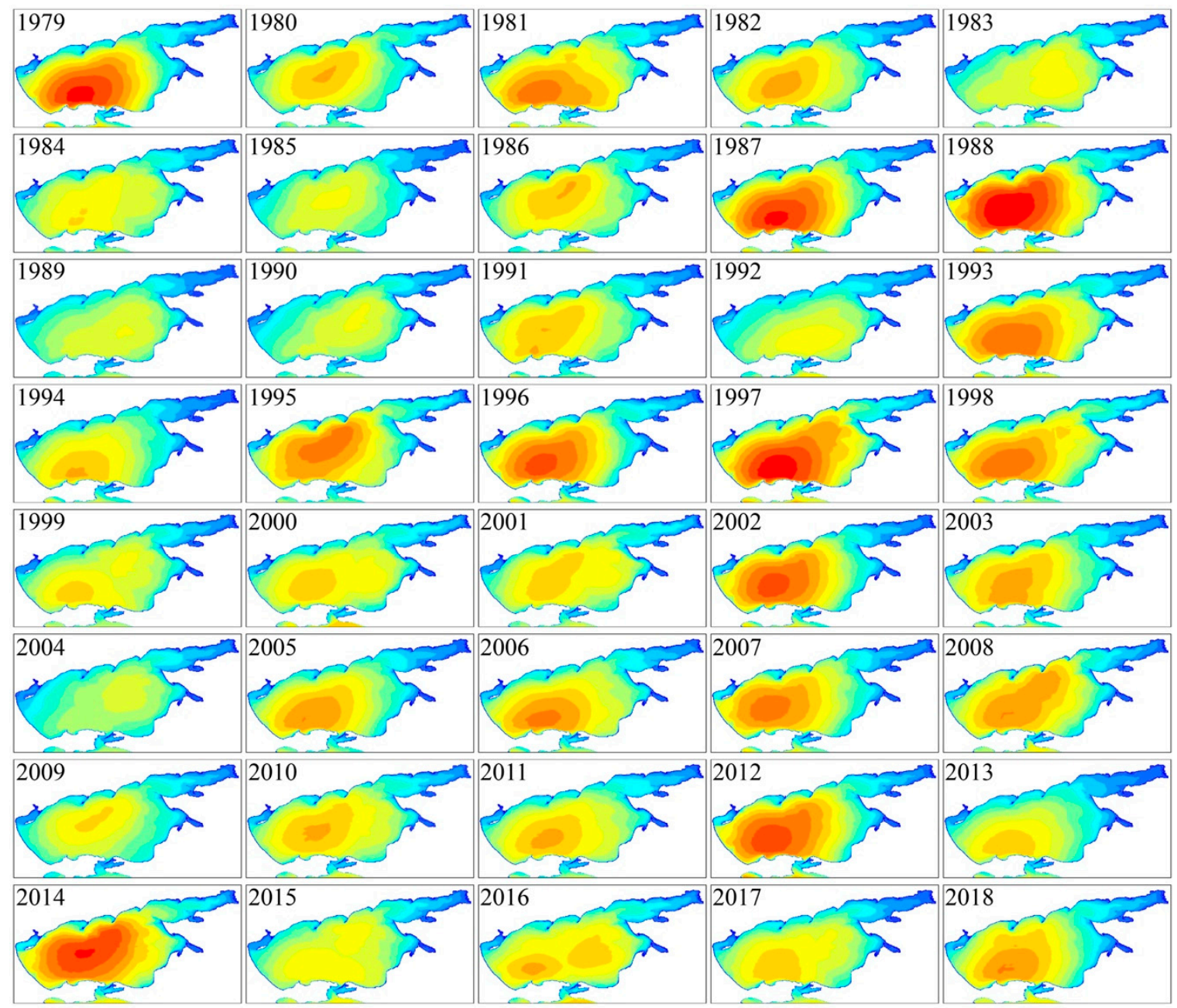

Hsig (m)

$0.0-0.2 \square 0.5-0.6 \square 0.9-1.0 \square 1.3-1.4 \square 1.7-1.8 \square 2.1-2.2 \square 2.5-2.6 \square 2.9-3.0$

$0.3-0.4 \square 0.7-0.8 \square 1.1-1.2 \square 1.5-1.6 \square 1.9-2.0 \square 2.3-2.4 \square 2.7-2.8 \square 3.1-4.0$

Figure 4. Annual maximum wave heights (m) according to calculations.

Since 1979, 72 synoptic situations, where an increase in storm activity in the Sea of Azov was possible, were distinguished. However, in certain cases, the increase in storms was limited by an ice cover of more than $20 \%$. According to the results, 49 storms were identified, and 4 were recorded in the warm half of the year. Out of that total, two of the largest storms were accompanied by upward surges on 11-12 April 1997 and 23-25 September 1997. In Figure 5, the dynamics of significant wave height are presented according to the calculation results and sea level observations during storms in the Sea of Azov.

Depending on the prevailing wind direction during a storm, an upward or downward surge was observed in the northern part of the sea and in Taganrog Bay. Therefore, against the background of the recorded storms, 16 downward and 15 upward surges were detected in combination with ice cover of up to $20 \%$ in winter periods.

During upward surges, the wave heights increased by the amount of the upward surge height in excess of sea level, leading to disastrous consequences. There was often a small downward surge before a strong upward surge. An example was the catastrophic storm and the upward surge on 24 September 2014, where the wave height in the central part of the sea exceeded $3.5 \mathrm{~m}$, and the upward surge in Taganrog Bay was $700 \mathrm{~cm}$.

The maximum wind waves (i.e., maximum wave heights) increased, as mentioned above, which was typical in the average long-term pattern for the cold season and the shifts into the summer-autumn period after 2002. At the same time, for the same season, the 
duration of wind waves with a height of 1.5-2.0 $\mathrm{m}$ increased. Despite the changes in the wave patterns, November-March remained the stormiest. There were no intra-day storm dynamics.
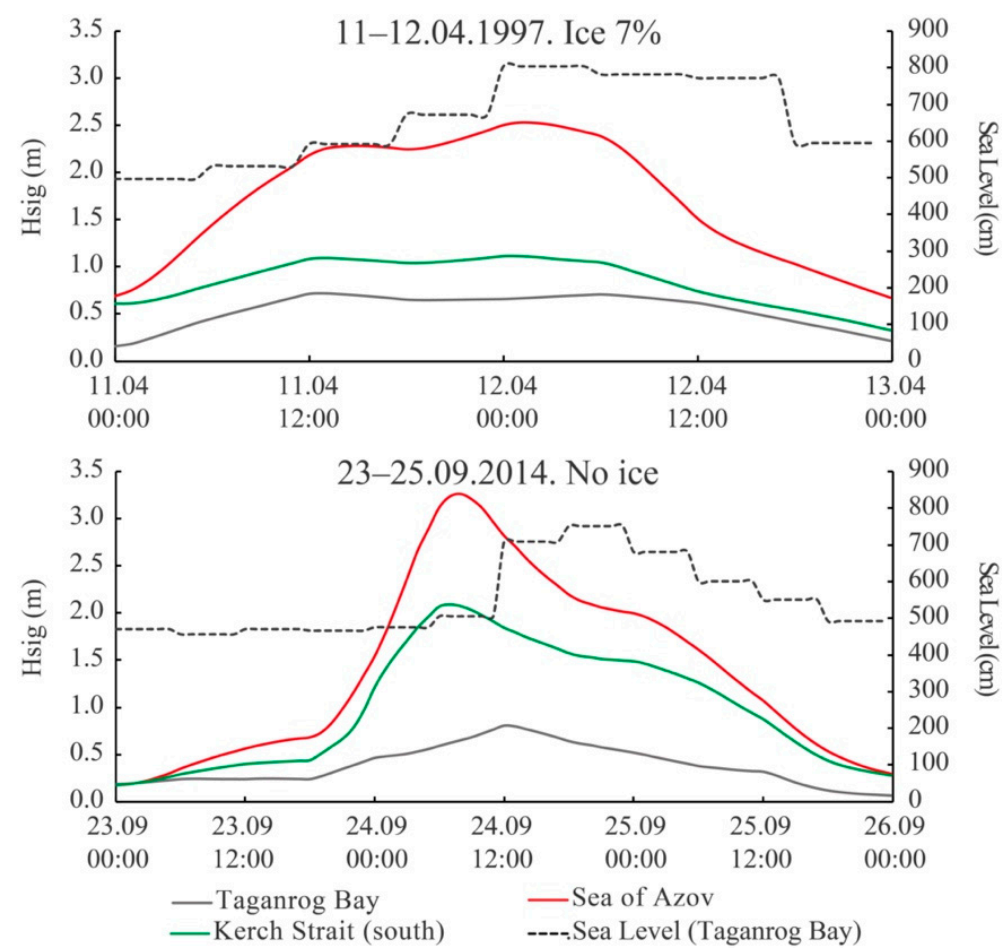

Figure 5. The dynamic of significant wave height $(\mathrm{m})$ and sea level in the Taganrog Bay $(\mathrm{cm})$ during storms in the Sea of Azov.

\section{Discussion}

Unlike the Black and Caspian Seas, there have not been any consistent, instrumental observations of waves in the Sea of Azov, and rarer still at coastal hydrometeorological stations. Furthermore, when calculating using modern mathematical models, the Sea of Azov has often been considered as an estuary of the Black Sea; therefore, information concerning bathymetry and coastline from global databanks was used, which yielded inaccurate values as a result, and the verification of the models were conducted based on observations of the Black Sea.

The parameters of wind waves and storms have been calculated using empirical formulas and were published as reference information in 1992 [33]. In 2006, reference data on the wind and wave patterns of the Baltic, North, Black, Azov, and Mediterranean seas were published by a team of authors in Russia [34]. This handbook has not lost its relevance and has been used to solve numerous applied problems; for example, when designing ships, it has been employed to classify ships by areas of navigation and in planning the work of a marine fleet.

The authors of [35] presented the results of their analysis of the climatic fields of currents in the Sea of Azov, including the significant wave heights and the power of the components of surface waves (e.g., wind waves and swell). They used modern hydrodynamic and spectral wave models while accounting for the ice cover of the basin. Without diminishing the merits of our colleagues, insufficient research has been conducted concerning storm activity and its combination with surges.

Statistical and cartographic analysis of the data in the present study was performed. The position of contours of highest average monthly wave heights $0.7-0.8 \mathrm{~m}$ are observed in the central and south-western part of the sea from November till March. Average monthly values 0.5-0.6 m mentioned at work Dyakov et al. [36], where authors calculated wave parameters using the SWAN model and based on the Japanese global atmospheric 
reanalysis project (JRA). The authors point out that according to visual observations, the wave height does not exceed $0.7 \mathrm{~m}$. At work [35], the mean values of significant heights of wind waves are $0.70-0.75 \mathrm{~m}$ in the relatively deep-water part of the sea.

The interannual dynamics of wind waves was characterized by the alternation of three five-year periods of wind wave strengthening and weakening (Figure 6). The moving average window was chosen based on the spectral analysis results. The optimal value of the moving average window was five, which allowed us to obtain the main trends without losing information.
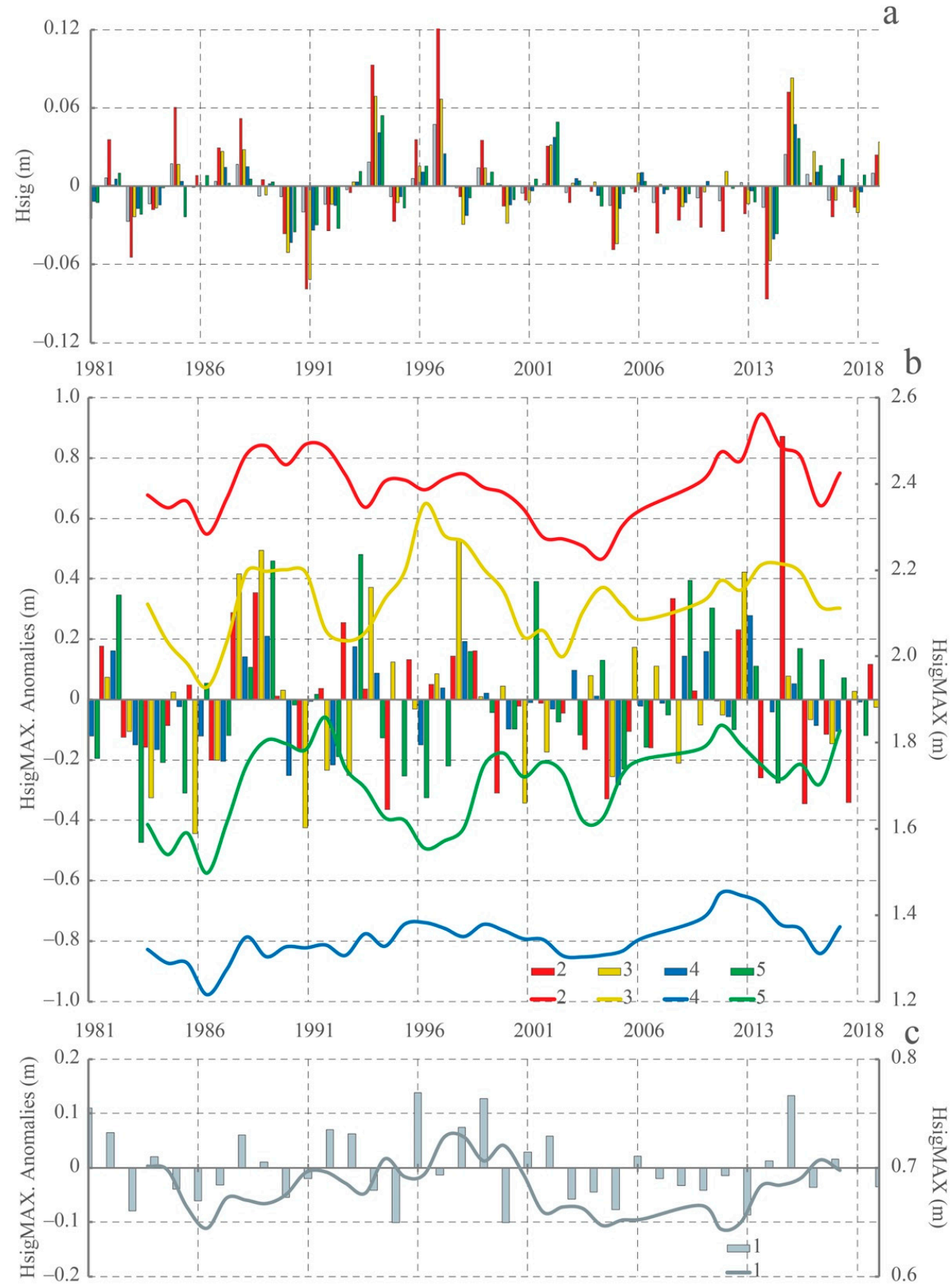

Figure 6. Interannual variation of anomalies of the average annual values of significant wave height. (a) The average annual significant wave height. (b) The maximum of significant wave height for each year. (c) The maximum of significant wave height in Taganrog Bay for each year. The lines indicate moving averages with a window width of 5 (additional y-axis). Where 1 is Taganrog Bay; 2 is the center of the Sea of Azov; 3, 4, 5 are the north, center, and south of the Kerch Strait, respectively. 
The period of 2002-2013 saw some stabilization in the average annual values. However, this was a consequence of leveling values within a year and then after 2002 the height of the waves increased in the summer and autumn seasons and decreased slightly in winter and spring. There was a shift of the storm season to a warmer period. The described trend was visible across the decades (Figure 7). This conclusion is confirmed on the basis of the analysis of the Innovative Polygon Trend Analysis Method (Figure 8, Table 3). The features of the method are considered in detail in the work [37,38]. For the Sea of Azov and the Taganrog Bay, we could see a significant increasing wave trend in July, August, and September; no trend in June; the decreasing trend was seen in January, February, March, May, October, November, and December. In the central part of the Kerch Strait, there was an increasing significant wave trend in February, April, July, August, September, October; no trend in June; decreasing trend in January, March, November, and December. The differences between the Kerch Strait and the Sea of Azov can be explained by the direct influence of the Black Sea in this area. Such dynamics should be considered when forecasting dangerous hydrometeorological phenomena, as strong storm events and prolonged small storms in the Sea of Azov can be accompanied by surges, and there is no ice cover at this time of year.
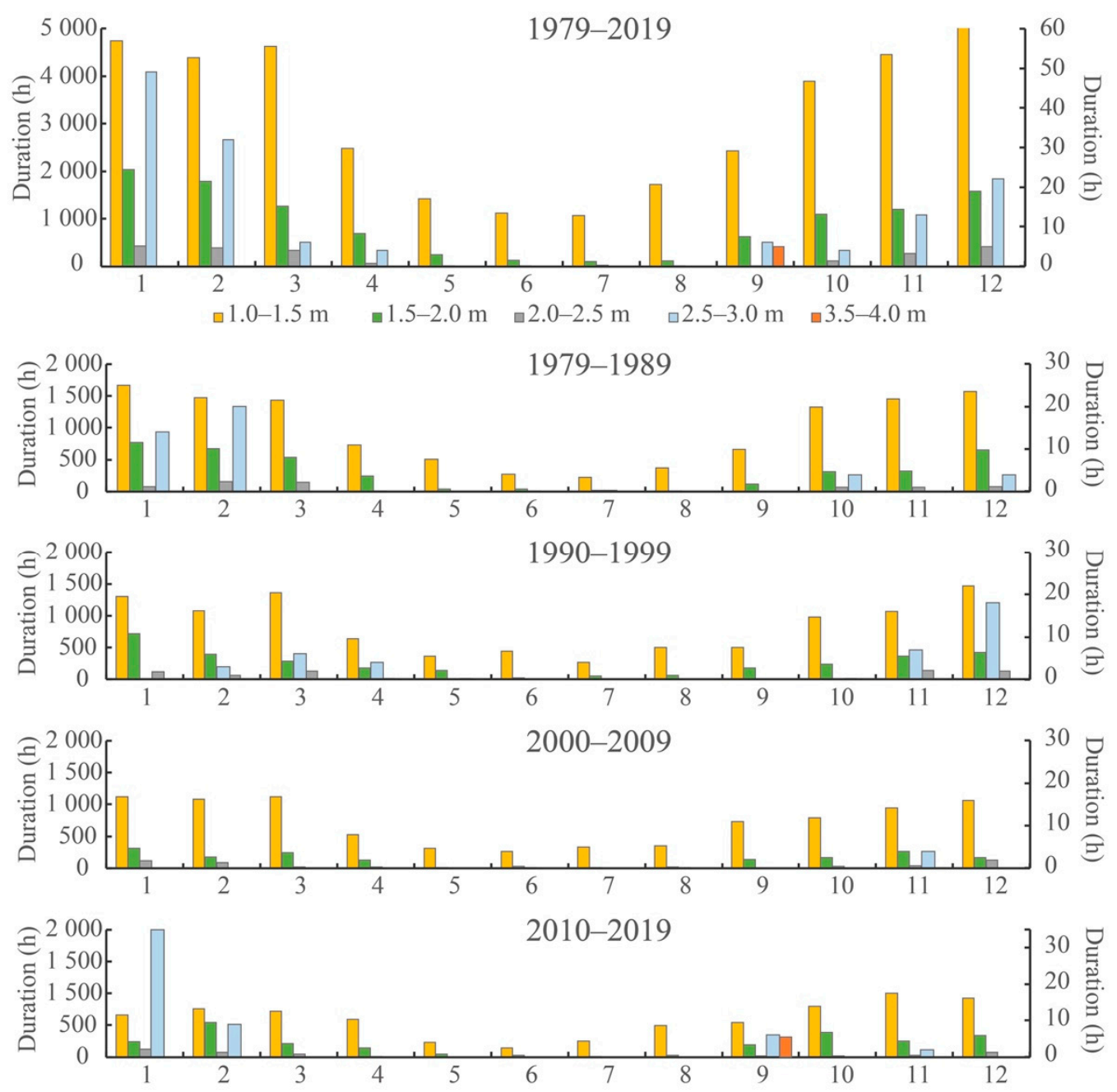

Figure 7. The total duration of wind waves (hour) of different heights in general and for ten-year periods in the Sea of Azov (excluding Taganrog Bay and the Kerch Strait). By the auxiliary axis, wind waves are $2.5 \mathrm{~m}$ or greater. 

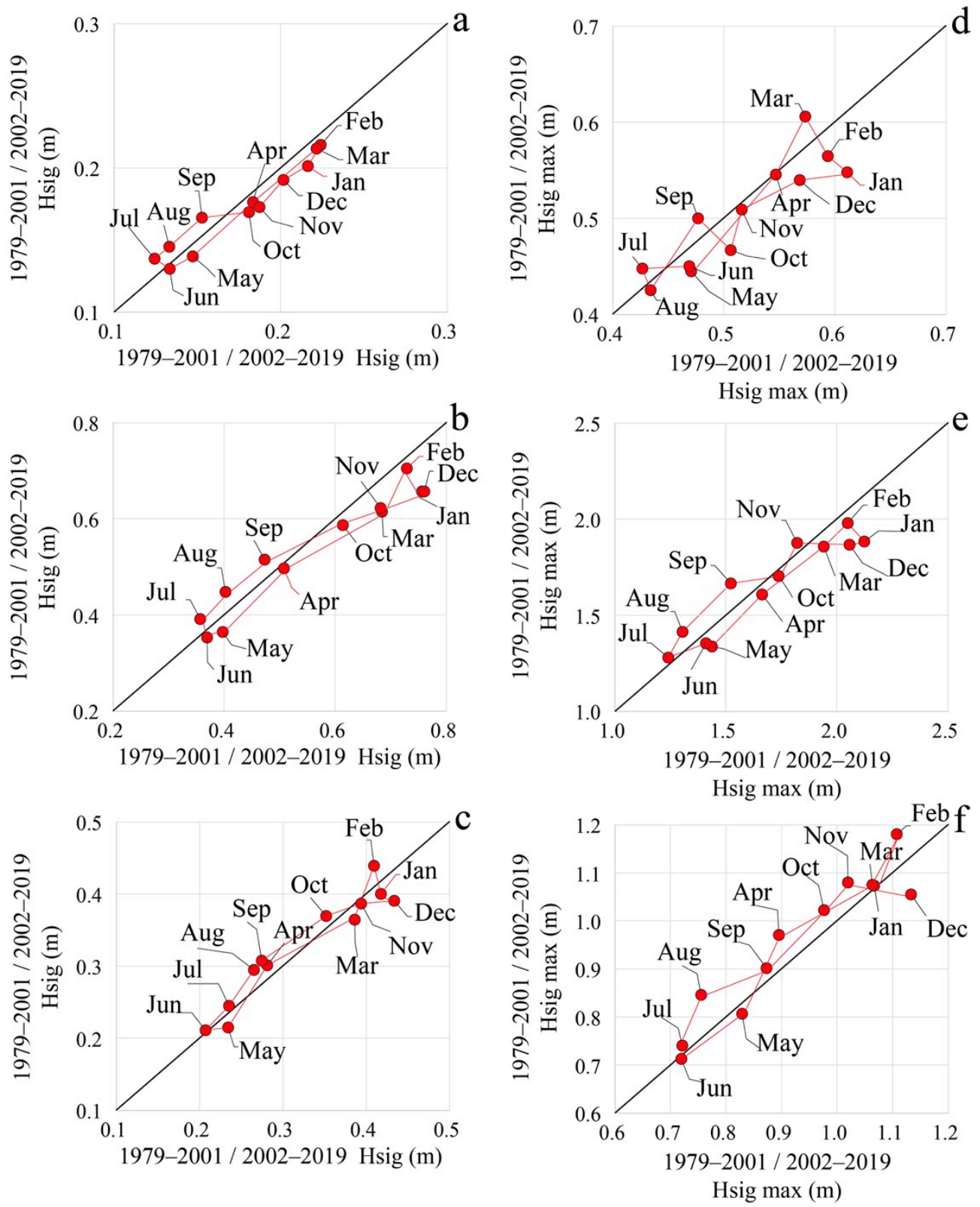

Figure 8. Innovative Polygon Trend Analysis Method graphics of significant wind wave monthly mean $(\mathbf{a}, \mathbf{b}, \mathbf{c})$ and average monthly maximum $(\mathbf{d}, \mathbf{e}, \mathbf{f})$ analysis results for each part of the Sea of Azov: $(\mathbf{a}, \mathbf{d})$-Taganrog Bay, $(\mathbf{b}, \mathbf{e})$-Sea of Azov, $(\mathbf{c}, \mathbf{f})$ - central part of the Kerch Strait.

The gradual increase in maximum wave heights after 2008 may be explained by the aridification of the region and by the concomitant increase in maximum wind speed against the background of a general decrease in average speeds.

In Taganrog Bay and in the northeastern part of the sea, dangerous storm phenomena occurred primarily during periods of low atmospheric pressure. This was due to the cyclones occurring over the Sea of Azov, which can be a cause of storm surges and can lead to extreme events under certain circumstances, for example, when moving through the Black Sea and the Kerch Strait. In Taganrog Bay, the values of wind waves were significantly lower than those in the Sea of Azov due to shallow depths and small size, the connection with the large Don River, and the presence of spits. Waves broke at shallow depths, but even with low wave heights, when combined with a storm surge, there can be devastating consequences for coastal infrastructure. 
Table 3. General evaluation of significant wind wave monthly mean (Hsig, $\mathrm{m}$ ) and average monthly maximum (Hsig max, m) analysis results for the Taganrog Bay, Sea of Azov, and Kerch Strait.

\begin{tabular}{|c|c|c|c|c|c|c|c|c|c|c|c|c|c|}
\hline & January & February & March & April & May & June & July & August & September & October & Nover & ecember & \\
\hline $\operatorname{Hsig}(\mathrm{m})$ & $y$ & $y$ & $y$ & 4 & $y$ & $\rightarrow$ & $\pi$ & $\lambda$ & $\lambda$ & $y$ & $y$ & $y$ & \\
\hline$\underset{\text { (m) }}{\text { Hsig max }}$ & $y$ & $y$ & $\pi$ & $\rightarrow$ & $y$ & 4 & $\pi$ & $y$ & $\pi$ & $y$ & $y$ & $y$ & Bay \\
\hline $\mathrm{Hsig}(\mathrm{m})$ & $y$ & $y$ & $y$ & 4 & $y$ & $y$ & $\pi$ & $\lambda$ & $\lambda$ & $y$ & $y$ & $y$ & Sea of \\
\hline$\underset{(\mathrm{m})}{\text { Hsig max }}$ & $y$ & 4 & 4 & $y$ & $y$ & $y$ & $\pi$ & $\pi$ & $\pi$ & $y$ & $\pi$ & $y$ & Azov \\
\hline Hsig (m) & $y$ & $\lambda$ & $y$ & $\lambda$ & $y$ & $\rightarrow$ & $\pi$ & $\lambda$ & $\pi$ & $\lambda$ & $y$ & 4 & Kerch \\
\hline$\underset{\text { (msig max }}{\text { max }}$ & $\lambda$ & $\lambda$ & $\lambda$ & $\lambda$ & $y$ & $y$ & $\pi$ & $\pi$ & $\pi$ & $\pi$ & $\pi$ & $y$ & $\begin{array}{c}\text { Strait } \\
\text { (center) }\end{array}$ \\
\hline
\end{tabular}

An upward surge increase in sea level by $700 \mathrm{~cm}$ or greater occurred with an almost complete absence of ice in the Sea of Azov, slightly elevated or close-to-normal (1013 hPa) atmospheric pressure, and west-southwest wind directions. An increase in sea level within $1-2 \mathrm{~m}$ can occur equally against the background of both low and high atmospheric pressure. At the same time, ice up to $20 \%$ can be observed in the sea during winter. The changes in wind direction provided the most intriguing information. At low atmospheric pressure, the prevailing direction could vary within the range of south to west, and at high pressure, southwest to west, with maximum speeds (i.e., greater than $15 \mathrm{~m} / \mathrm{s}$ ). An increase in sea level to $1 \mathrm{~m}$ also occurred, as in the previous case, against the background of reduced (with SE and NW winds) or increased (with SW winds) atmospheric pressures. In addition, the proportion of the sea area occupied by ice increased in winter and varied widely from $0 \%$ to $40 \%$. At the maximum ice cover in winter, there was a minimal increase in sea level and in slight wind waves.

During a storm, the areas with the maximum wave height were concentrated in the central part of the Sea of Azov. The relative symmetry in the configuration of the coastline and the limited depth did not allow areas with strong waves to migrate, as, for example, has been observed in the Black Sea.

In the Kerch Strait, active wind waves have often been observed that, given the narrow width of the strait, can lead to an increase in dangerous conditions for navigation and a partial or complete cessation of economic activity in the strait. Matishov et al. (2008) [39] described a storm observed on November 11, 2007, that caused serious damage to four vessels, as well as to coastal facilities in the Kerch Strait. The wind speed was reached $30 \mathrm{~m} / \mathrm{s}$ SW direction, the wave height in the center of the Kerch Strait reached $2.1 \mathrm{~m}$ by our calculation (6 Beaufort by observations [39]). This was the reason for the growth of the water level in the strait and the formation of upsurge. At the same time, E winds were observed in the Taganrog Bay, which led to the formation of downsurge in this part of the sea at $1.65 \mathrm{~m}$. From the Black Sea side of the Kerch Strait, the highest of significant wave height was $8.31 \mathrm{~m}$ by results Akpinar et al. [13] and $6.52 \mathrm{~m}$ by Arkhipkin et al. [40].

\section{Conclusions}

The calculations presented provide new knowledge about storm waves, its intensity and duration and the combination of wind waves with surges. In this study, the most accurate bathymetry data and information concerning the coastline were used in the calculations of waves and storms. As a result, we obtained the most accurate information presented, to date, regarding waves in the Sea of Azov, as compared to previous studies. It is shown for the first time that, after 2002, the height of the waves in the Sea of Azov increased in the summer and autumn seasons and decreased slightly in winter and spring, and shifting of the storm season to a warmer period. All values of wind waves for all storm situations from 1979 to 2019 have been established. Comparison with surge phenomena has been made. 
The shores of the Sea of Azov have been severely damaged during storm events. Based on the calculated values of storm waves, future research will examine the dynamic loads on the coast, which may improve forecasts and improve assessments of the seacoast abrasion and zoning according to the degree of danger. Areas for optimal development of land use subject to the installation of bank protection structures will be identified; the types of coastal developments required for a particular stretch of coastline will be recommended. This research could be useful for planning socioeconomic activities in the region.

Funding: The study was funded by the Russian Science Foundation (project No. 20-77-00083).

Institutional Review Board Statement: Not applicable.

Informed Consent Statement: Not applicable.

Data Availability Statement: Not applicable.

Conflicts of Interest: The authors declare no conflict of interest.

\section{References}

1. Goryushina, E.M.; Yaitskaya, N.A. Dangerous Hydrometeorological Phenomena in the Azov-Black Sea Region. Eur. Proc. Soc. Behav. Sci. EpSBS 2019, 78, 1150-1154.

2. Matishov, G.G.; Matishov, D.G. Current natural and social risks in the Azov-Black Sea region. Her. Russ. Acad. Sci. 2013, 83, 490-498. [CrossRef]

3. Matishov, G.G.; Bespalova, L.A.; Ivlieva, O.V.; Tsygankova, A.E.; Kropyanko, L.V. The Sea of Azov: Recent abrasion processes and problems of coastal protection. Dokl. Earth Sci. 2016, 471, 1269-12721. [CrossRef]

4. $\quad$ Cavaleri, L.; Abdallab, S.; Benetazzoa, A.; Bertottia, L.; Bidlotb, J.-R.; Breivikc, Ø.; Carniela, S.; Jensend, R.E.; Portilla-Yandune, J.; Rogersf, W.E.; et al. Wave modelling in coastal and inner seas. Prog. Oceanogr. 2018, 167, 164-233. [CrossRef]

5. Rusu, E.; Soares, C.G. Wave modelling at the entrance of ports. Ocean. Eng. 2011, 38, 2089-2109. [CrossRef]

6. Pallares, E.; Sánchez-Arcilla, A.; Espino, M. Wave energy balance in wave models (SWAN) for semi-enclosed domains-Application to the Catalan coast. Cont. Shelf Res. 2014, 87, 41-53. [CrossRef]

7. Mao, M.; Van Der Westhuysen, A.J.; Xia, M.; Schwab, D.J.; Chawla, A. Modeling wind waves from deep to shallow waters in Lake Michigan using unstructured SWAN. J. Geophys. Res. Ocean. 2016, 121, 3836-3865. [CrossRef]

8. Medvedeva, A.Y.; Arkhipkin, V.S.; Myslenkov, S.A.; Zilitinkevich, S.S. Wave climate of the Baltic Sea following the results of the swan spectral model application. Vestn. Mosk. Univ. Ser. 5 Geogr. 2015, 1, 12-22.

9. Myslenkov, S.A.; Platonov, V.S.; Toropov, P.A.; Shestakova, A.A. Simulation of storm waves in the Barents Sea. Vestn. Mosk. Univ. Ser. 5 Geogr. 2015, 6, 65-75.

10. Kislov, A.V.; Surkova, G.V.; Arkhipkin, V.S. Occurence frequency of storm wind waves in the Baltic, Black, and Caspian Seas under changing climate conditions. Russ. Meteorol. Hydrol. 2016, 41, 121-129. [CrossRef]

11. Yaitskaya, N.A. Retrospective analysis of wind waves in the Caspian Sea in the second half of the XX-beginning of the XXI century and its connection with the regional climate changes. Geogr. Bull. 2017, 2, 57-70. [CrossRef]

12. Akpınar, A.; Van Vledder, G.P.; Kömürcü, M.İ.; Özger, M. Evaluation of the numerical wave model (SWAN) for wave simulation in the Black Sea. Cont. Shelf Res. 2012, 50, 80-99. [CrossRef]

13. Akpınar, A.; Bingölbalia, B.; Van Vledder, G.P. Wind and wave characteristics in the Black Sea based on the SWAN wave model forced with the CFSR winds. Ocean. Eng. 2016, 126, 276-298. [CrossRef]

14. Van Vledder, G.P.; Akpınar, A. Wave model predictions in the Black Sea: Sensitivity to wind fields. Appl. Ocean. Res. 2015, 53, 161-178. [CrossRef]

15. Bingölbali, B.; Akpınar, A.; Jafali, H.; Van Vledder, G.P. Downscaling of wave climate in the western Black Sea. Ocean. Eng. 2019, 172, 31-45. [CrossRef]

16. Berdnikov, S.V.; Dashkevich, L.V.; Kulygin, V.V.; Sheverdyaev, I.V.; Tretyakova, I.A.; Yaitskaya, N.A. Ex-Mare-forecasting system of natural hazards in the Azov Sea region. Geogr. Environ. Sustain. 2018, 11, 29-45. [CrossRef]

17. Holthuijsen, L.H.; Booij, N.; Ris, R.C. A spectral wave model for the coastal zone. In Ocean Wave Measurement and Analysis; American Society of Civil Engineers: New York, NY, USA, 1993; pp. 630-641.

18. Ris, R.C.; Holthuijsen, L.H.; Booij, N. A third-generation wave model for coastal regions: 2, verification. J. Geophys. Res. 1999, 104, 7667-7681. [CrossRef]

19. Booij, N.; Holthuijsen, L.H.; Ris, R.C. A third-generation wave model for coastal regions. Model description and validation. J. Geophys. Res. 1999, 104, 7649-7666. [CrossRef]

20. Zijlema, M.; Van der Westhuyse, A.J. On convergence behavior and numerical accuracy in stationary SWAN simulations of nearshore wind wave spectra. Coast. Eng. 2005, 52, 237-256. [CrossRef]

21. Matishov, G. Bathymetry and patterns of formation of the bottom relief of the Sea of Azov. In Ecosystem Studies of the Azov, Black, Caspian Seas; Matishov, G., Ed.; Kola Scientific Centre of the Russian Academy of Sciences: Apatity, Russia, 2006 ; pp. 31-42. 
22. Matishov, G.; Levitus, S.; Matishov, D.; Gargopa, Y.; Dashkevich, L.; Berdnikov, S.; Kulygin, V.; Arkhipova, O.; Chikin, A.; Shabas, I.; et al. Climatic Atlas of the Sea of Azov 2008; NOAA/NESDIS: Washington, DC, USA, 2008; p. 103.

23. Magaeva, A.A.; Tretyakova, I.A. Creation of a digital elevation model of the Sea of Azov bottom. In Ecology Economy Informatics; Matishov, G., Ed.; Southern Federal University: Rostov-on-Don, Russia, 2015; pp. 266-269.

24. Yaitskaya, N.A. The results of hindcasting experiments of wind wave in the Sea of Azov (as illustrated by winters 2015-2017). Sci. South Russ. 2017, 13, 60-70. [CrossRef]

25. Azov Research Institute of Fisheries. Available online: http:/ /www.azniirkh.ru (accessed on 28 January 2021).

26. The ERA-Interim Archive Version 2.0. Available online: http://www.ecmwf.int/node/8174 (accessed on 28 December 2021).

27. Yaitskaya, N.; Tretyakova, I. Mathematical Modeling of Dangerous Storm and Surge Phenomena in the Basin of the Sea of Azov (24 March 2013). In Proceedings of the 16th International Multidisciplinary Scientific GeoConference SGEM 2016, Albena, Bulgaria, 28 June-7 July 2016; pp. 481-488. [CrossRef]

28. The Unified State System of Information on the World Ocean. Available online: http:/ / portal.esimo.ru/portal (accessed on 28 December 2021).

29. Komen, G.; Hasselmann, S.; Hasselmann, K. On the existence of a fully developed wind sea spectrum. J. Phys. Oceanogr. 1984, 14, 1271-1285. [CrossRef]

30. Hasselmann, K.; Barnett, T.P.; Bouws, E.; Carlson, H.; Cartwright, D.E.; Enke, K.; Ewing, J.A.; Gienapp, H.; Hasselmann, D.E.; Kruseman, P.; et al. Measurements of Wind-Wave Growth and Swell Decay during the Joint North Sea Wave Project (JONSWAP). Ergänzungsheft Zur Dtsch. Hydrogr. Z. 1973, 8, 1-95.

31. Yaitskaya, N.A.; Magaeva, A.A. Dynamics of the ice regime of the Sea of Azov in the XX-XXI centuries. Led I Sneg 2018, 58, 373-386. [CrossRef]

32. Matishov, G.G.; Grigorenko, K.S. Currents of the Azov Sea during the Don River Low-Water Period. Oceanology 2021, 61, 173-182. [CrossRef]

33. Hydrometeorology and hydrochemistry of the USSR Seas. Vol. 5. The Sea of Azov; Goptarev, N.P., Simonova, A.I., Zatuchnaya, B.M., Gershanovich, D.E., Eds.; Gidrometeoizdat: St. Petersburg, Russia, 1991; p. 237.

34. Reference Data on the Wind and Wave Regime of the Baltic, North, Black, Azov and Mediterranean Seas; Lopatoukhin, L.I., Bukhanovsky, A.V., Ivanov, S.V., Chernyshova, E.S., Eds.; Russian Maritime Register of Shipping: St. Petersburg, Russia, $2006 ;$ p. 452.

35. Divinsky, B.V.; Kosyan, R.D.; Fomin, V.V. Climatic Fields of Sea Currents and Wind Waves of the Sea of Azov. Dokl. Earth Sci. 2021, 501, 976-988. [CrossRef]

36. Dyakov, N.N.; Fomin, V.V.; Polozok, A.A. Climatic characteristics of waves in the Sea of Azov based on the observation data and reanalysis. Proc. State Oceanogr. Inst. 2015, 216, 60-78.

37. Achite, M.; Ceribasi, G.; Ceyhunlu, A.I.; Wałega, A.; Caloiero, T. The Innovative Polygon Trend Analysis (IPTA) as a Simple Qualitative Method to Detect Changes in Environment-Example Detecting Trends of the Total Monthly Precipitation in Semiarid Area. Sustainability 2021, 13, 12674. [CrossRef]

38. Sen, Z.; Sisman, E.; Dabanli, I. Innovative Polygon Trend Analysis (IPTA) and applications. J. Hydrol. 2019, 575, 202-210. [CrossRef]

39. Matishov, G.G.; Satitskiy, R.M.; Inzheneykin, Y.I. Conditions and consequences of shipwreck in the Kerch Strait in the storm on 11 November 2007. Sci. South Russ. 2008, 4, 54-63.

40. Arkhipkin, V.S.; Gippius, F.N.; Koltermann, K.P.; Surkova, G.V. Wind waves in the Black Sea: Results of a hindcast study. Nat. Hazards Earth Syst. Sci. 2014, 14, 2883-2897. [CrossRef] 